\title{
PENATALAKSANAAN HIPERTENSI DENGAN RELAKSASI OTOT PROGRESIF PADA LANSIA DI PANTI SOSIAL TRESNA WERDHA BUDI LUHUR KOTA JAMBI
}

\author{
Hasyim Kadri' ${ }^{1)}$, Salvita Fitrianti $\left.{ }^{2}\right)$ \\ ${ }^{1,2}$ Program Studi S1 Keperawatan, STIKes Baiturrahim Jambi \\ Email : h451mkadri87@yahoo.com
}

\begin{abstract}
ABSTRAC
The high hypertension in Jambi City where the elderly are individuals who are prone to hypertension. Elderly people in Jambi City can be found in the community, one of them is Budi Luhur Jambi Tresna Werdha Home (PSTW). Social institutions are residential institutions with the elderly who are physically or healthily still independent, but have limitations in the socioeconomic field. According to the PSTW Budi Luhur Jambi elderly people can still experience diseases such as hypertension. The number of elderly people suffering from hypertension at Budi Luhur PSTW in Jambi City in November 2018 amounted to 22 elderly with a total of 9 men and 13 women, out of a total of 70 elderly in the Budi Luhur PSTW in Jambi City. Tareget the outcome of this activity officers and sufferers can do progressive muscle relaxation techniques in hypotensive patients at Budi Luhur PSTW, Jambi City
\end{abstract}

Keywords: Hypertension; Progressive Muscle Relaxation Technique.

\begin{abstract}
ABSTRAK
Tingginya hipertensi di Kota Jambi dimana lansia merupakan individu yang rentan terkena hipertensi. Lansia di Kota Jambi dapat ditemukan di masyarakat salah satunya di Panti Sosial Tresna Werdha (PSTW) Budi Luhur Jambi. Panti sosial merupakan suatu institusi hunian bersama para lansia yang secara fisik atau kesehatan masih mandiri, akan tetapi mempunyai keterbatasan di bidang sosial ekonomi. Menurut pihak PSTW Budi Luhur Jambi lansia tetap dapat mengalami penyakit seperti hipertensi. Jumlah lansia yang menderita hipertensi di PSTW Budi Luhur Kota Jambi pada bulan November 2018 berjumlah 22 lansia dengan jumlah laki-laki 9 orang dan perempuan 13 orang, dari jumlah lansia yang ada di PSTW Budi Luhur Kota Jambi yang berjumlah 70 orang. Tareget luaran kegiatan ini petugas dan penderita bisa melakukan teknik relaksasi otot progresif pada penderita hipetensi di PSTW Budi Luhur Kota Jambi. Evaluasi Hasil, $85 \%$ peserta mampu memahami tentang materi yang disampaikan. Disankan kepada petugas panti agar lebih memperhatikan kesehatan lansia khususnya dalam malakukan latihan teknik relaksasi otot progresif secara rutin.
\end{abstract}

Kata Kunci : Hipertensi; Teknik Relaksasi Otot Progresif 


\section{PENDAHULUAN}

Hipertensi adalah salah satu faktor penyebab bebrbagai penyakit yang berhubungan dengan kardiovaskuler seperti stroke, serangan jantung, gagal jantung dan merupakan penyebab utama gagal ginjal kronik. Akibat lain yang ditimbulkan tekanan darah yang selalu tinggi adalah pendarahan selaput bening, pecahnya pembuluh darah di otak serta kelumpuhan. Jika tekanan darah semakin tinggi maka semakin berat pula kerja jantung dan jika tidak segera diobati jantung akan menjadi lemah untuk melaksanakan beban tambahan. Hal tersebut memungkinkan terjadinnya penyempitan pembuluh darah dan gagal jantung dengan gejala seperti kelelahan, napas pendek, serta kemungkinan terjadi pembengkakan pada kaki (Sutanto, 2010).

Tingginya hipertensi di Kota Jambi dimana lansia merupakan individu yang rentan terkena hipertensi. Lansia di Kota Jambi dapat ditemukan di masyarakat salah satunya di Panti Sosial Tresna Werdha (PSTW) Budi Luhur Jambi. Panti sosial merupakan suatu institusi hunian bersama para lansia yang secara fisik atau kesehatan masih mandiri, akan tetapi mempunyai keterbatasan di bidang sosial ekonomi. Menurut pihak PSTW Budi Luhur Jambi lansia tetap dapat mengalami penyakit seperti hipertensi. Walaupun aktifitas sehari hari lansia sudah di jadwalkan seperti setiap hari sabtu senam, ada juga lansia yang tidak mau ikut senam, sehingga beresiko untuk terkena penyakit.

Tabel. 1 Jumlah penderita hipertensi di Panti Tresna Werda Budi Luhur Jambi 2018

\begin{tabular}{llcc}
\hline No & Umu & Laki-laki & Perempuan \\
\hline 1 & $60-74$ & 7 & 9 \\
2 & $75-90$ & 2 & 4 \\
& Total & 9 & 13 \\
\hline
\end{tabular}

Berdasarkan tabel 1.2 diatas dapat disimpulkan bahwa jumlah lansia yang menderita hipertensi di PSTW Budi Luhur Kota Jambi pada bulan November 2018 berjumlah 22 lansia dengan jumlah laki-laki 9 orang dan perempuan 13 orang, dari jumlah lansia yang ada di PSTW Budi Luhur Kota Jambi yang berjumlah 70 orang (PSTW Budi Luhur Jambi, 2018).

Pemberian terapi non farmakologis relatif praktis, efisien dan dapat menekan pengeluaran. Beberapa jenis terapi non farmakologis diantaranya akupresure, terapi jus, pijat, yoga, pengobatan herbal, pernafasan dan relaksasi, relaksasi otot progresif merupakan salah satu teknik relaksasi (Bulecheck, dkk 2013 dalam Erwanto, dkk 2017). Herodes mengatakan bahwa teknik relaksasi otot progresif memusatkan perhatian pada suatu aktivitas otot dengan mengidentifikasi otot yang tegang kemudian menurunkan ketegangan dengan melakukan teknik relaksasi untuk mendapatkan perasaan relaks (Setyoadi \& Kushariyadi, 2011).

Relaksasi progresif dilakukan dengan cara klien menegangkan dan melemaskan sekelompok otot secara berurutan dan memfokuskan perhatian pada perbedaan perasaan yang dialami antara saat kelompok otot relaks dan saat otot tersebut kejang. Jacobsen (1938), penemu teknik relaksasi progresif, menemukan bahwa ketegangan sekelompok otot sebelum relaksasi sebenarnya mencapai derajat relaksasi yang lebih besar dibandingkan hanya sekedar memerintahkan seseorang untuk relaks. Teknik ini dapat menurunkan konsumsi oksigen, metabolisme, frekuensi pernapasan, frekuensi jantung, tegangan otot, dan tekanan darah sistolik dan diastolik (Kozier, 2010).

Hipertensi ini sering ditemukan pada lansia sejalan dengan bertambahnya umur semakin menurun pula elastisitas pembuluh darah, kemudian faktor stress yang dapat memicu terjadinya hipertensi pada lansia umumnya lansia di PSTW Budi Luhur Jambi belum mengatur pola makan seperti lebih memilih membeli makanan dari luar seperti gorengan ketimbang makanan yang sudah disediakan di panti, kurangnya konsumsi buah-buahan dan sayur-sayuran merupakan salah satu faktor terjadinya hipertensi pada 
lansia. Selanjutnya bertanya tentang aktifitas sehari-hari lansia, Lansia mengatakan setiap hari sabtu rutin mengikuti senam namun satu dari lima lansia yang hipertensi mengatakan hanya tinggal di dalam wisma. Mereka belum mengetahui tentang terapi relaksasi otot progresif, baik cara maupun manfaatnya untuk menurunkan tekanan darah.

\section{TARGET DAN LUARAN}

Target Luaran dalam kegiatan ini adalah melatih petugas kesehatan dan melakukan teknik relaksasi otot progresif pada penderita hipertensi di PSTW Budi Luhur Kota Jambi

\section{METODE PELAKSANAAN}

Pengabdian kepada masyarakat ini dilakukan pada setiap Kamis, Jumat dan Sabtu bulan Januari 2018 di PSTW Budi Luhur Kota Jambi. Adapun tahap pelaksanaan Pengabdian kepada Masyarakat ini melakukan pelatihan tentang relaksasi otot progresif di PSTW Budi Luhur Kota Jambi. Metode pelaksanaan kegiatan ini berupa : Pendidikan kesehatan pola makan penderita hipertensi, pelatihan petugas Klinik Pstw Budi Luhur dan Penerapan Teknik relaksasi otot progresif pada penderita hipertensi. Adapun materi pelatihan adalah sebagai berikut :

Teknik relaksasi otot progresif terdiri dari 14 gerakan otot yang berurutan menurut Setyoadi \& Kushariyadi (2011), sebagai berikut:

1. Gerakan 1: ditujukan untuk melatih otot tangan

a. Genggam tangan kiri sambil membuat suatu kepalan

b. Buat kepalan semakin kuat sambil merasakan sensasi ketegangan yang terjadi

c. Pada saat kepalan dilepaskan, klien dipandu untuk merasakan relaks selama 10 detik d. Gerakan pada tangan kiri ini dilakukan dua kali sehingga klien dapat membedakan perbedaan antara ketegangan otot dan keadaan relaks yang dialami

e. Prosedur serupa juga dilakukan pada tangan kanan

2. Gerakan 2: ditujukan untuk melatih otot tangan bagian belakang.

Tekuk kedua lengan kebelakang pada pergelangan tangan sehingga otot ditangan bagian belakang dan lengan bawah menegang, jari-jari menghadap kelangit-langit.

3. Gerakan 3: ditujukan untuk melatih otot biseps (otot besar pada bagian atas pangkal lengan)

a. Genggam kedua tangan sehingga menjadi kepalan

b. Kemudian membawa kedua kepalan ke pundak sehingga otot biseps akan menjadi tegang.

4. Gerakan 4: ditujukan untuk melatih otot bahu supaya mengendur

a. Angkat kedua bahu setinggi-tingginya seakan-akan menyentuh kedua telinga

b. Fokuskan perhatian gerakan pada kontras ketegangan yang terjadi dibahu, punggung atas dan leher.

5. Gerakan 5 dan 6: ditujukan untuk melemaskan otot-otot wajah (seperti otot dahi, mata, rahang dan mulut)

a. Gerakan otot dahi dengan cara mengerutkan dahi dan alis sampai otot terasa dan kulitnya keriput

b. Tutup keras-keras mata sehingga dapat dirasakan ketegangan disekitar mata dan otot-otot yang mengendalikan mata

6. Gerakan 7: ditujukan untuk mengendurkan ketegangan yang dialami oleh rahang, katupkan rahang diikuti dengan menggigit gigi sehingga terjadi ketegangan disekitar otot rahang.

7. Gerakan 8: ditujukan untuk mengendurkan otot-otot sekitar mulut. Bibir dimoncongkan sekuat-kuatnya sehingga dirasakan ketegangan di sekitar mulut. Gerakan 5,6,7 dan 8 liat gambar 4 
8. Gerakan 9: ditujukan untuk merileksasikan otot leher bagian depan maupun belakang

a. Gerakan diawali dengan otot leher bagian belakang bahu kemudian otot leher bagian depan

b. Letakkan kepala sehingga dapat beristirahat

c. Tekan kepala pada permukaana bantalan kursi sedemikian rupa sehingga dapat merasakan ketegangan di bagian belakang leher dan punggung atas.

9. Gerakan 10: ditujukan untuk melatih otot leher bagian depan

a. Gerakan membawa kepala ke muka

b. Benamkan dagu kedada, sehingga dapat merasakan ketegangan didaerah leher bagian muka.

10. Gerakan 11: ditujukan untuk melatih otot punggung

a. Angkat tubuh dari sandaran kursi

b. Punggung dilengkungkan

c. Busungkan dada, tahan kondisi tegang selama 10 detik, kemudian rileks

d. Daat rileks letakkan tubuh kembali ke kursi sambil membiarkan otot menjadi lemas.

11. Gerakan 12: ditujukan untuk melemaskan otot dada

a. Tarik napas panjang untuk mengisi paru-paru dengan udara sebanyakbanyaknya

b. Ditahan selama beberapa saat, sambil merasakan ketegangan di bagian dada sampai turun keperut, kemudian dilepas

c. Saat ketegangan dilepas, lakukan napas normal dengan lega

12. Ulangi lagi sehingga dapat dirasakan perbedaan antara kondisi tegang dan relaks. Gerakan 13: ditujukan untuk melatih otot perut

a. Tarik dengan kuat perut kedalam

b. Tahan sampai menjadi kencang dan keras selama 10 detik, lalu lepaskan

c. Ulangi kembali seperti gerakan awal untuk perut ini.
13. Gerakan 14 : ditujukan untuk melatih otot-otot kaki (seperti paha dan betis).

a. Luruskan kedua telapak kaki sehingga otot paha terasa tegang

b. Lanjutkan dengan mengunci lutut sedemikian rupa sehingga ketegangan pindah ke otot betis.

c. Tahan posisi tegang selama 10 detik, lalu lepaskan

d. Ulangi setiap gerakan masing-masing dua kali.

\section{HASIL DAN PEMBAHASAN}

Hasil yang dicapai dalam kegiatan ini antara lain : Pelaksanaan Pengabdian pada masyarakat dimulai dari pengajuan izin pelaksanaan kepada Kepala PSTW Budi Luhur Kota Jambi. Sebelum memberikan pelatihan terlebih diberikan penjelasan tentang kegiatan yang akan dilaksanakan dan meminta persetujuan. Kemudian diberikan pendidikan kesehatan pola makan penderita hipertensi, pelatihan petugas klinik PSTW Budi Luhur dan Penerapan Teknik relaksasi otot progresif pada penderita hipertensi. Pelaksanaan kegiatan dilakukan di ruang aula PSTW Budi Luhur Kota Jambi pada Januari 2018. Evaluasi pelaksanaan Pengabdian kepada masyarakat dibagi menjadi 3 evaluasi yaitu: Evaluasi Struktur, Penyuluhan tentang pola makan penderita hipertensi, pelatihan petugas klinik PSTW Budi Luhur dan Penerapan Teknik relaksasi otot progresif pada penderita hipertensi yang berperan sebagai presenter dan instruktur adalah Ns. Hasyim Kadri, S.Kep, M.Kes dibantu oleh Salvita Fitrianti .MKM.. Semua anggota berperan secara baik dan sesuai dengan rencana. Pelaksanaan pengabdian ini dibantu oleh 3 orang mahasiswa yang bertugas sebagai fasilitator dan moderator. Evaluasi Proses, Selama proses berlangsung lansia dan petugas klinik sangat antusias dan aktif dalam latihan dan diskusi. Sebanyak $85 \%$ peserta bertanya terkait dengan materi yang disampaikan. Selama proses berlangsung tidak ada peserta yang keluar 
masuk ruangan .Selama penyuluhan dan pelatihan Presenter mampu berinteraksi dengan baik kepada seluruh peserta. Evaluasi Hasil, $85 \%$ peserta mampu memahami tentang materi yang disampaikan. Rencana Tindak lanjut yang perlu dilakukan untuk kegiatan ini : Melakukan kegitan dengan rutin dan terjadwal di PSTW Budi Luhur Kota Jambi.

\section{KESIMPULAN DAN SARAN}

\section{Kesimpulan}

Kesimpulan Pelaksanaan pengabdian kepada masyarakat di PSTW Budi Luhur Kota Jambi yang dilakukan oleh dosen STIKes Baiturrahim dan Mahasiswa berjalan dengan baik. Peserta yang hadir sangat antusias dalam bertanya dan praktek yang diberikan oleh moderator dan instruktur.

\section{Saran}

Kepada petugas panti agar lebih memperhatikan kesehatan lansia khususnya dalam malakukan latihan teknik relaksasi otot progresif secara rutin.

\section{UCAPAN TERIMA KASIH}

Terimakasih disampaikan kepada Sekolah Tinggi Ilmu Kesehatan Baiturrahim yang telah memberikan dukungan dana serta kepada pihak Panti yang telah memfasilitasi kegiatan ini sehingga kegiatan ini dapat terlaksana dengan baik.

\section{DAFTAR PUSTAKA}

Asikin, M. dkk. 2016. Keperawatan medikal bedah: Sistem Kardiovaskuler. Erlangga: Jakarta.

Aspiani, R.Y. 2014. Asuhan Keperawatan Gerontik Jilid 2. Trans Info Media: Jakarta

Efendi Ferry, (2009), Keperawatan Kesehatan Komunitas, Teori dan praktik dalam keperawatan, Jakarta:Salemba Medika

Notoatmodjo, 2007. Promosi Kesehatan dan Ilmu Perilaku, Jakarta:Rineka Cipta

Syafrudin, 2009. Buku Ajar Ilmu Kesehatan Masyarakat untuk Mahapeserta Kebidanan. Jakarta :

Undang-undang RI No 39, 2009

Wahit Iqbal Mubarak, 2009, Ilmu Keperawatan Komunitas, Jakarta: Salemba Medika 